\title{
Agronomy and Economy: Impact of Tillage and Poultry Manure on Mazie (Zea mays L.)
}

\author{
Hafiz Muhammad Rashad Javeed1,2, Muhammad Shahid Ibni Zamir1', Nasir Masood ${ }^{3}$, \\ Rafi Qamar', Muhammad Shehzad5, Muhammad Nadeem ${ }^{3 *}$ \\ ${ }^{1}$ Department of Agronomy, University of Agriculture, Faisalabad, Pakistan \\ ${ }^{2}$ Department of Environmental Science, NFC Institute of Engineering and Technology, Multan, Pakistan \\ ${ }^{3}$ Department of Environmental Sciences, COMSATS Institute of Information Technology, Vehari, Pakistan \\ ${ }^{4}$ Department of Agronomy, University College of Agriculture, University of Sargodha, Pakistan \\ ${ }^{5}$ Department of Agronomy, Faculty of Agriculture, University of Poonch Rawalakot, Azad Kashmir, Pakistan \\ Email: ${ }^{*}$ muha.nadeem@gmail.com
}

Received 27 December 2013; revised 11 February 2014; accepted 28 February 2014

Copyright () 2014 by authors and Scientific Research Publishing Inc.

This work is licensed under the Creative Commons Attribution International License (CC BY).

http://creativecommons.org/licenses/by/4.0/

(c) (i) Open Access

\section{Abstract}

Seedling emergence and seedling establishment are two important phases for the good crop stand and final maize crop harvest. A field study was conducted to explore the effects of different tillage practices and poultry manure levels on the seedling emergence, growth, development, yield, and economics of the spring planted maize during 2010 and 2011. Experimental treatments include four tillage treatments (zero, minimum, conventional and deep tillage) and three poultry manure amendments (control (no manure), $5 \mathrm{Mg} \cdot \mathrm{ha}^{-1}$ and $10 \mathrm{Mg} \cdot \mathrm{ha} \mathrm{a}^{-1}$ ). Seedling emergence was linearly affected as the tillage intensity was increased. Significant relationship of tillage with leaf area index, leaf area duration, crop growth rate, net assimilation rate and total dry matter was recorded during the both years. Poultry manure at the rate of $10 \mathrm{Mg} \cdot \mathrm{ha}^{-1}$ produced the higher leaf area index, leaf area duration, crop growth rate, total dry matter and grain yield as compared to 5 $\mathrm{Mg} \cdot \mathrm{ha}^{-1}$ and control. Moreover, experimental results concluded that the deep tillage practice has taken less time to start emergence. Similarly, higher values trend of leaf area index, leaf area duration, crop growth rate, total dry matter accumulation and grain yield was shifted from deep tillage to conventional, minimum and zero tillage practices during both years. Economically, the minimum tillage with poultry manure at rate of $10 \mathrm{Mg} \cdot \mathrm{ha}^{-1}$ gave the better benefit to cost ratio and crop productivity as compared to conventional, deep and zero tillage. The experiment suggested the minimum tillage with poultry manure at the rate of $10 \mathrm{Mg}^{\circ} \mathrm{ha}^{-1}$ may ensure the maize grain yield sustainability.

${ }^{*}$ Corresponding author.

How to cite this paper: Javeed, H.M.R., Zamir, M.S.I., Masood, N., Qamar, R., Shehzad, M. and Nadeem, M. (2014) Agronomy and Economy: Impact of Tillage and Poultry Manure on Mazie (Zea mays L.). American Journal of Plant Sciences, 5, 799-810. http://dx.doi.org/10.4236/ajps.2014.56094 


\section{Keywords}

\section{Agronomy; Economy; Leaf Area Index; Maize; Seedling Growth; Tillage; Pakistan}

\section{Introduction}

In Pakistan, maize ranks $3^{\text {rd }}$ cereal crop after wheat and rice with an estimated area of 1083 thousand hectares having an annual production of 4271 thousand tones [1]. No doubt, at a time many factors including insect pest attack, diseases, weeds infestation, irrigation, steadily seasonal changes and post-harvest losses are responsible for the low yield of maize, but the tillage is most important one [2]. Tillage is directly correlated with nitrogen (N) recovery and deep tillage improved the root growth, root proliferation and $\mathrm{N}$ recovery efficiency. Higher $\mathrm{N}$ recovery efficiency was recorded in the sub-soiling treatments compared to the compacted or no tilled soil [3]. Higher biological and grain yield, improved root growth and highest average plant height were noted in the conventional tillage over no tillage [4] [5]. Chisel ploughing resulted in yield losses varying from $14 \%$ in dry matter yield to $30 \%$ in final grain yield [6]. Similarly, increased crop growth rate and soya yield from deep tillage are ascribed to deeper roots penetration which resulted in easy access to water, minerals and nutrients to the plants particularly during the dry season [7]. The combine use of the poultry manure and the $\mathrm{N}$ sources increase the crop grain yield, water use efficiency and fertilizer use efficiency which shows the synergetic relationship between the organic matter and the $\mathrm{N}$ fertilizers [8]. Poultry manure treatments produced higher values for maize plant height, leaf area index and biomass. Maize grain yield was significantly higher when the farm yard manure was applied along with the lower level of NPK [9]. The application of mineral fertilizers with the organic manures can sustain the crop yield and the cropping systems through better nutrient recycling during the complete growing season [10] [11] and also increase the chlorophyll content in maize [12] [13]. The present study is planned to explore the influence of tillage practices and different poultry manure levels on the maize seedling emergence and growth with special reference to economic of maize during spring season in the subtropical conditions of Faisalabad, Pakistan.

\section{Materials and Methods}

\subsection{Site and Layout}

The field experiment was conducted at the Agronomic Research Area, Department of Agronomy, University of Agriculture, Faisalabad, Pakistan during 2010. The same experiment was repeated during spring season in 2011. The experimental site is located in subtropical region at $31^{\circ} \mathrm{N}$ latitude and $73^{\circ} \mathrm{E}$ longitude on the globe with 184 $\mathrm{m}$ altitude. The soil samples at depth of $0-30 \mathrm{~cm}$ were taken manually with the help of soil auger before the start of experiments during both years. All the collected sub soil samples were completely mixed and a homogenous soil sample is formed. Soil samples are subjected to various physico-chemical analyses as shown in Table 1(a).

Maize crop was sown on March 4 and February 26 during spring 2010 and 2011, respectively. The experiment was carried out in randomized complete block design with split plot arrangements keeping the tillage practices in the main plots; zero tillage (direct seed sowing with dibbler), minimum tillage (one cultivation with normal cultivator followed by planking), conventional tillage (2 - 3 cultivations with normal cultivator followed by planking) and deep tillage (two deep ploughing with chisel plough + one cultivation with normal cultivator followed by planking). Sub plot treatments were composed on three poultry manure levels; control (no poultry manure), poultry manure @ $5 \mathrm{Mg} \cdot \mathrm{ha}^{-1}$ and poultry manure @ $10 \mathrm{Mg} \cdot \mathrm{Ma}^{-1}$. The one year old poultry manure was used and subjected to chemical analysis before application in each year.

\subsection{Crop Husbandry}

Maize (Pioneer 32F10) was used as test variety during the both years of study. The net plot size was $10 \mathrm{~m} \times 4.5$ $\mathrm{m}$. The plant population 81,510 plants $\cdot \mathrm{ha}^{-1}$ was maintained by keeping $\mathrm{R} \times \mathrm{R} 75 \mathrm{~cm}$ and $\mathrm{P} \times \mathrm{P} 22 \mathrm{~cm}$. The crop was sown by using seed rate of $25 \mathrm{~kg} \cdot \mathrm{ha}^{-1}$. Recommended nutrients requirements of maize crop were applied both from poultry manure and chemical fertilizers after the poultry manure analysis. At first, the crop require- 
Table 1. Physiochemical analysis of soil and poultry manure. (a) Physiochemical analysis of soil; (b) Physiochemical analysis of manure.

(a)

\begin{tabular}{ccccccc}
\hline Characteristics & $\mathbf{p H}$ & $\mathbf{E C}\left(\mathbf{d S m}^{-\mathbf{1}}\right)$ & Organic matter (\%) & Total N (\%) & Available P (ppm) & Available K (ppm) \\
\hline 2010 & 7.9 & 1.12 & 0.62 & 0.062 & 7.38 & 290 \\
2011 & 7.7 & 1.2 & 0.78 & 0.069 & 7.32 & 294 \\
\hline
\end{tabular}

(b)

\begin{tabular}{ccccc}
\hline Composition & Nitrogen (\%) & Phosphorus $\left(\mathbf{P}_{\mathbf{2}} \mathbf{O}_{\mathbf{5}} \mathbf{\%}\right)$ & Potassium $\left(\mathbf{K}_{\mathbf{2}} \mathbf{O}\right.$ \%) & Dry matter (\%) \\
\hline 2010 & 2.02 & 1.15 & 1.71 & 72.85 \\
2011 & 2.06 & 1.17 & 1.73 & 74.03 \\
\hline
\end{tabular}

ment was fulfilled from poultry manure and then the remaining from the chemical fertilizers. Nitrogen, phosphorous and potash was applied at the rate of 380, 210 and $162 \mathrm{~kg} \cdot \mathrm{ha}^{-1}$ in the form of urea, di-ammonium phosphate and murate of potash, respectively. Whole of phosphorous, potash and half of nitrogen was applied at the time of sowing while remaining half of nitrogen was top dressed at the time of $2^{\text {nd }}$ irrigation. Hoeing was done twice with help of a hand hoe after $1^{\text {st }}$ and $2^{\text {nd }}$ irrigation to curtail the weeds problem.

\subsection{Procedures to Measure the Parameters}

Temperature, relative humidity and rainfall were recorded during the both study years. During 2010, the temperature in March was relatively lower as compared to 2011. The time to start emergence was recorded as the first seedling came out from the soil surface. Leaf area meter was used to determine the leaf area of the crop at 15 days interval. The measurements of leaf area were started from $25^{\text {th }}$ days after sowing (DAS) and were continued till the 100 DAS. For this purpose, five plants from each plot were harvested and their leaves were separated. The leaves were than cleaned with the tissues gently to clean the soil on the leaf surface and the leaf area was measured. Leaf area index was measured using the leaf area meters following the standard procedures and time to start emergence (days). Leaf area index (LAI), leaf area duration (LAD), crop growth rate (CGR) and harvest index (HI) was calculated by using the equations;

$$
\begin{gathered}
\text { LAI }=\text { Leaf Area/Land Area } \\
\mathrm{LAD}=\left(\mathrm{LAI}_{1}-\mathrm{LAI}_{2}\right) \times\left(\mathrm{T}_{2}-\mathrm{T}_{1}\right) / 2 \\
\mathrm{CGR}=\mathrm{W}_{2}-\mathrm{W}_{1} / \mathrm{T}_{2}-\mathrm{T}_{1} \\
\mathrm{HI}=(\text { Grain yield/biological yield }) \times 100
\end{gathered}
$$

The five plants (which were taken for the leaf area) were used to find out the dry matter accumulation. Chaffed sample were sundried after taking the fresh weight of the sample and then put the sample in the oven at $70^{\circ} \mathrm{C} \pm 5^{\circ} \mathrm{C}$ for further drying. The samples were kept into the oven till the constant weight was achieved.

\subsection{Economic Analysis}

The partial budget of the both experiments was made using the inputs and outputs prices of the local market of Faisalabad, Pakistan following the procedures as described in the chapter 3 of CYMMT training manual [14].

Benefit to cost ratio (BCR): Large farmland owners are more interested in the benefit to cost ration rather than net return. The gross income and total expenditure was calculated in local currency (rupees; Rs.). It was calculated by using the equation;

$$
\mathrm{BCR}=\text { Gross Income/Total Expenditures }
$$

Marginal rate of return: The marginal analysis of variance further refines the treatments recommendations and composed of three parts; marginal cost $\left(\mathrm{Rs} \cdot \mathrm{ha}^{-1}\right)$, marginal net benefit $\left(\mathrm{Rs}_{\mathrm{h}} \mathrm{ha}^{-1}\right)$ and marginal rate of return (MRR in \%). All these were calculated using the methodology explained in chapter 3 on CYMMT training manual [14]. The following formula was used to calculate the MRR;

MRR $=($ Marginal Net Benefit/Marginal Cost $) \times 100$ 


\section{Results}

\subsection{Seedling Emergence}

Significantly higher number of days was taken by zero tillage sown crop treated with higher dose of poultry manure to emerge from the soil surface as shown in Figures 1(a) and (b).

Maximum number of days was taken in zero tillage treatment (8.5 \& 9.8) to emergence from the soil surface (Figures 1(a) and (b)) during 2010 and 2011, respectively. Significantly less number of days to start the emergence was taken by crop sown in deep tillage treatment. The plants emerged on an average 6.3 and 8.2 days after sowing in deep tillage treatment during 2010 and 2011, respectively (Figures 1(a), (b)). Conventional tillage and minimum tillage are at par with the zero tillage for days to start emergence parameter as shown in Figures 1 (a) and (b)).

As far as poultry manure treatments were concerned, the less time to start emergence ( 5 days) were counted in the control followed by the plot where the $5 \mathrm{Mg} \cdot \mathrm{ha}^{-1}$ (Figures 1 (a) and (b)) poultry manure was applied. The

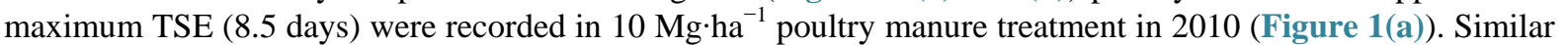
data trend was observed during 2011 growing season (Figure 1(b)).

\subsection{Growth Analysis}

Significantly, higher numeric values of leaf area index (LAI: 5.01 \& 5.33) were recorded at 55 DAS during the both years of study in the deep tillage, while the lower LAI values were noted in zero tillage sown crop (4.62 \& 5.01) as shown in Figures 2(a) and (b)), during 2010 and 2011.

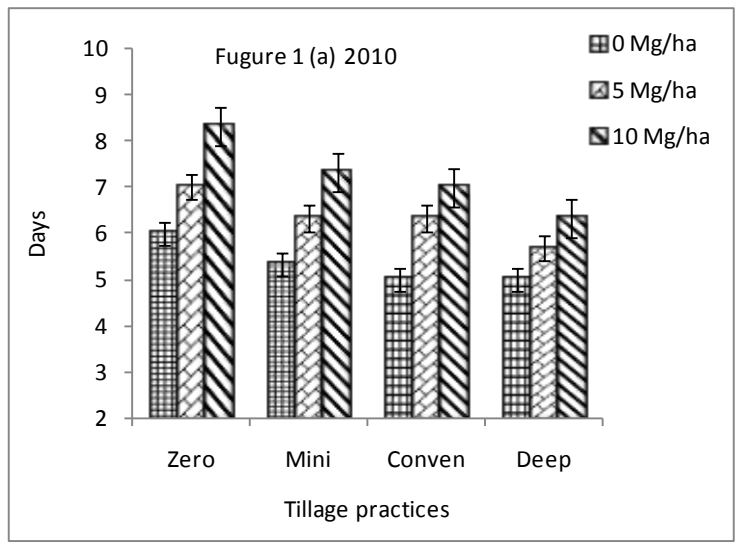

(a)

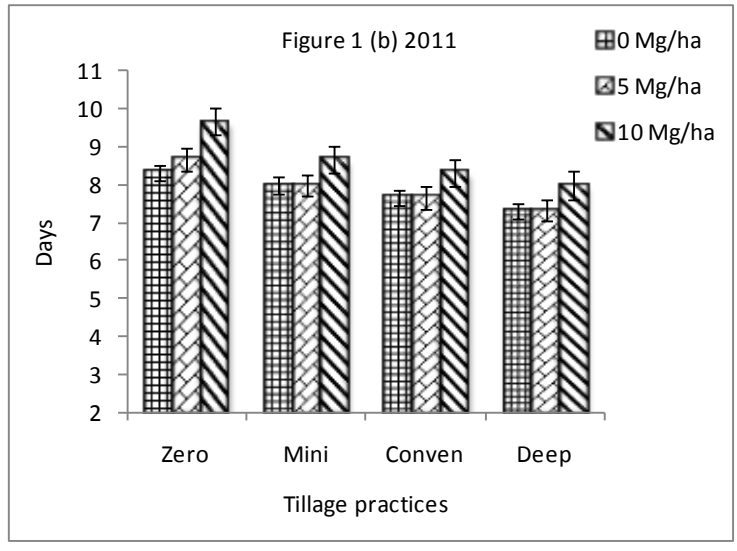

(b)

Figure 1. Time to start emergence as influenced by different tillage practices (a) and poultry manure levels (b) during 2010 and 2011. 

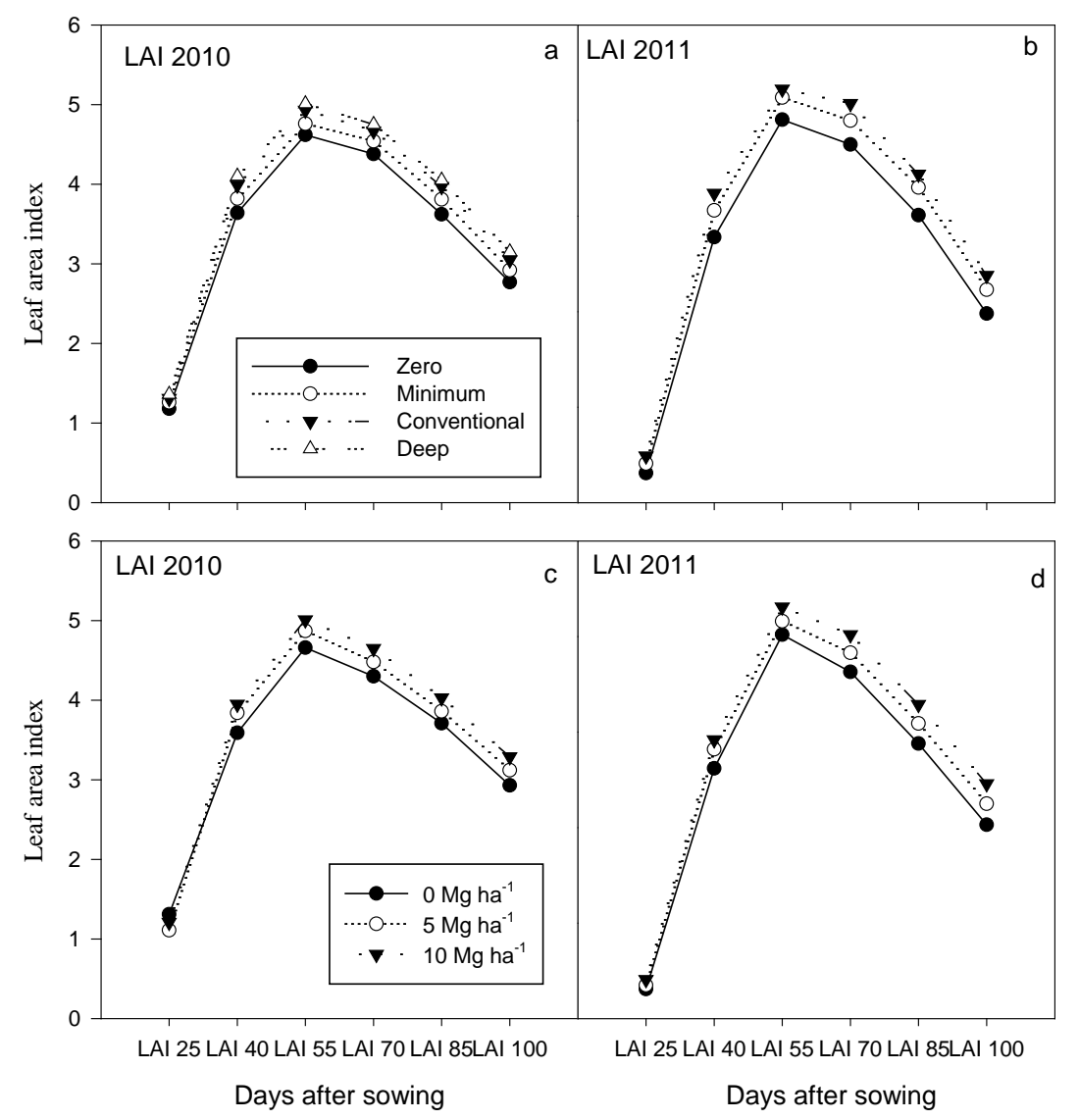

Figure 2. Leaf area index as influenced by different tillage practices (a) (b) and poultry manure levels (c) (d) during 2010 and 2011, respectively.

Leaf area index of maize in conventional (4.93 \& 5.24) and minimum tillage (4.76 \& 5.15) sown crop was intermediate of deep tillage and zero tilled sown crop during 2010 \& 2011 growing season, respectively (Figures 2(a) and (b)). The similar leaf area index trend was observed in poultry manure treatments as shown in Figures 2(c) and (d)). A substantial increase in LAI was observed with the increase in the dose of poultry manure. Maximum leaf area was observed on 55 DAS in $10 \mathrm{Mg} \cdot \mathrm{ha}^{-1}$ poultry manure treatments during both study years (Figures 2(c) and (d)).

In case of leaf area duration (LAD), cumulative data regarding LAD indicated that the significantly higher LAD (Figures 3(a), (d)) was observed in the deep tillage crop (302 days) that was statistically at par with those of conventional tillage crop (296 days) which was followed by the minimum tillage sown crop (285 days). The lower LAD (273 days) was recorded in the zero tilled sown crop during the 2010 as shown in Figures 3(a) and (d). Similarly in 2011, maximum leaf area duration (324 days) was recorded in the deep tilled sown crop that was followed by the conventional tillage sown crop (313 days) which was statistically at par with those of minimum tillage sown crop (307 days) as shown in Figures 3(a) and (d). The minimum LAD (295 days) was observed in the zero tillage sown maize crop as sown in Figures 4(a) and (d). As far as poultry manure data was concerned; Substational increase in leaf area duration was observed with the increase in the dose of poultry manure as compared to control. In 2010, more days of leaf area duration (289 days) were achieved in the treatment where poultry manure @ $10 \mathrm{Mg} \cdot \mathrm{ha}^{-1}$ was applied followed by the $5 \mathrm{Mg} \cdot \mathrm{ha}^{-1}$ poultry manure treatment.

The maximum crop growth rate (CGR) was recorded in deep tillage sown crop in $2010\left(23.67 \mathrm{gm}^{-2} \mathrm{~d}^{-1}\right)$ followed by the conventional tillage $\left(22.38 \mathrm{gm}^{-2} \mathrm{~d}^{-1}\right)$ and the minimum tillage sown crop $\left(21.79 \mathrm{gm}^{-2} \mathrm{~d}^{-1}\right)$ as shown in Figures 4(a) and (d). The minimum CGR was noted in the zero tillage sown crop (20.99 $\left.\mathrm{gm}^{-2} \mathrm{~d}^{-1}\right)$ during 2010 as shown in Figures 4(a) and (d). As far as poultry manure data was concerned; Substational increase in CGR was observed with the increase in the dose of poultry manure as compared to control. Higher crop growth rate $\left(23.45 \mathrm{gm}^{-2} \mathrm{~d}^{-1}\right)$ was achieved in the treatment where poultry manure @ $10 \mathrm{Mg} \cdot \mathrm{ha}^{-1}$ was applied followed 

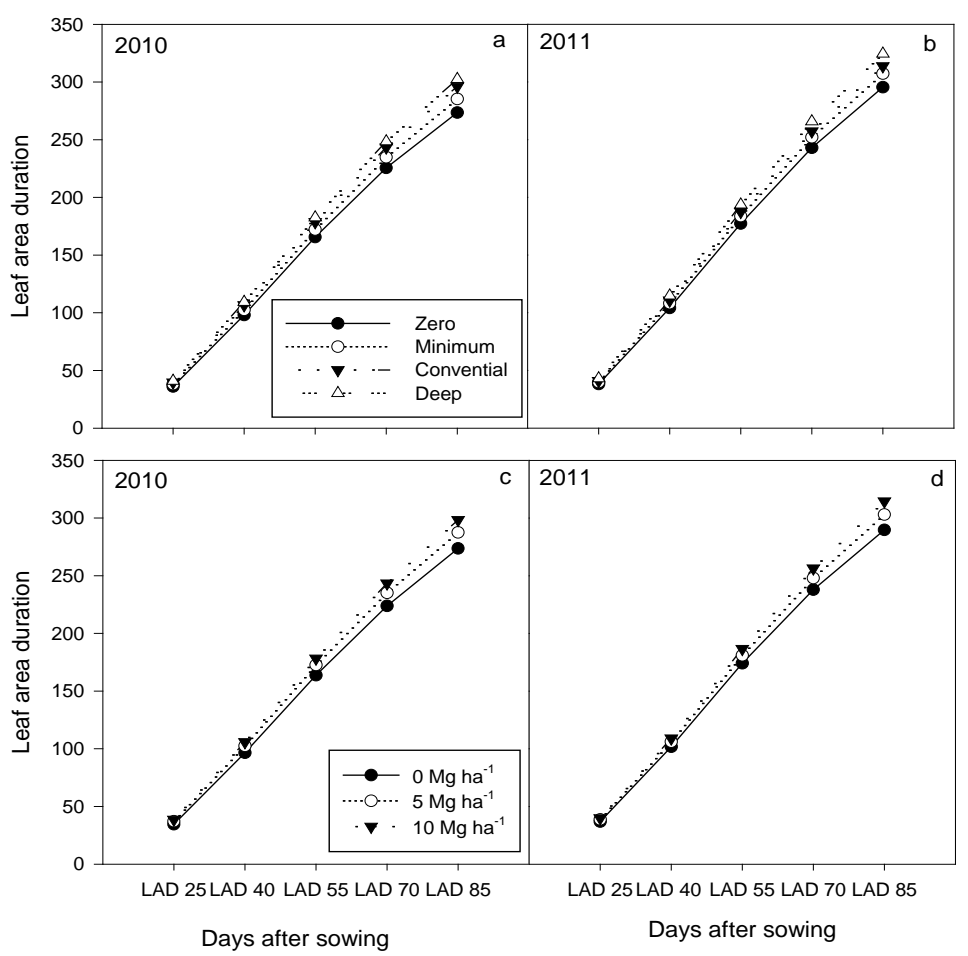

Figure 3. Leaf area duration (LAD) as influenced by different tillage practices (a) (b) and poultry manure levels (c) (d) during 2010 and 2011, respectively.
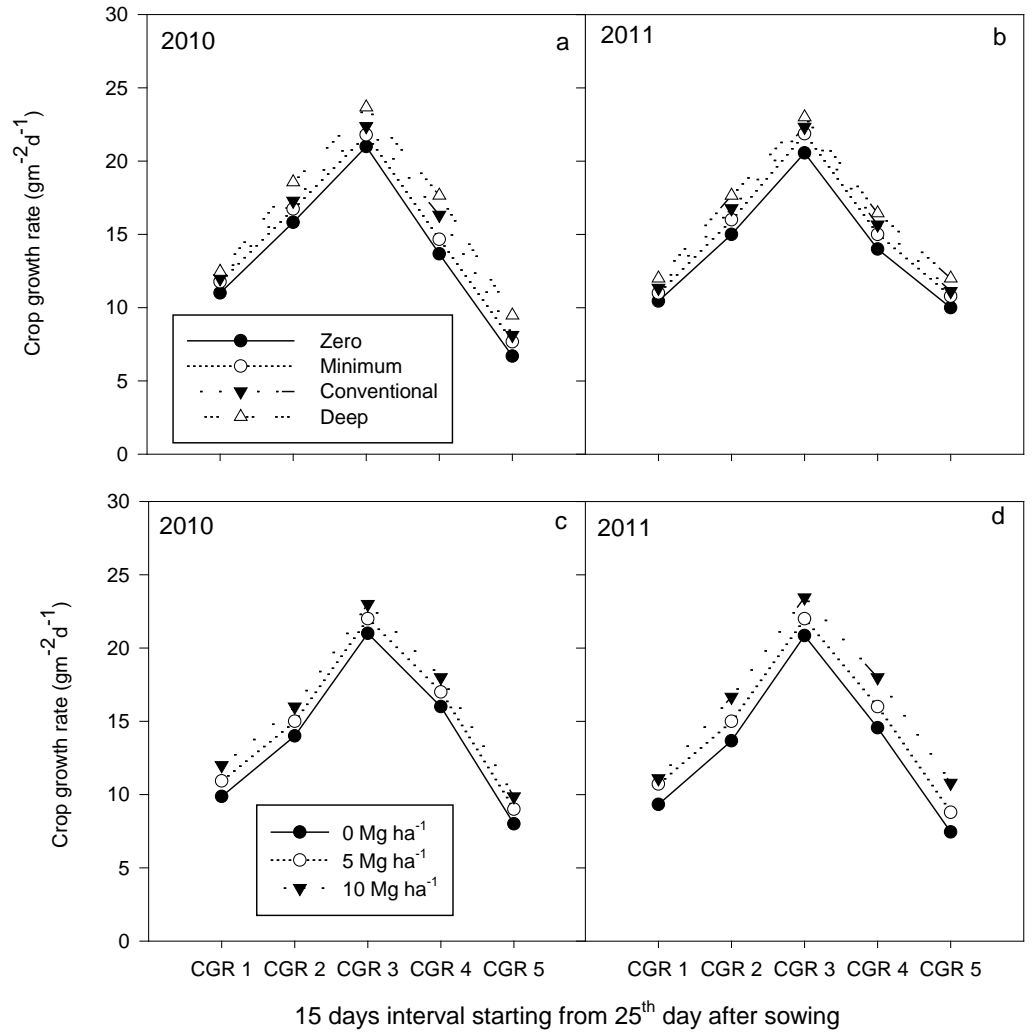

Figure 4. Crop growth rate as influenced by different tillage practices (a) (b) and poultry manure levels (c) (d) during 2010 and 2011, respectively. 


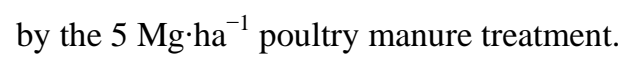

Statistically higher net assimilation rate (NAR) was recorded in the control $\left(6.18 \mathrm{gm}^{-2} \mathrm{~d}^{-1}\right)$ treatment during the year 2010 followed by the $5 \mathrm{Mg} \cdot \mathrm{ha}^{-1}$ poultry manure treatment $\left(6.17 \mathrm{gm}^{-2} \mathrm{~d}^{-1}\right)$ while the lower NAR was ex-

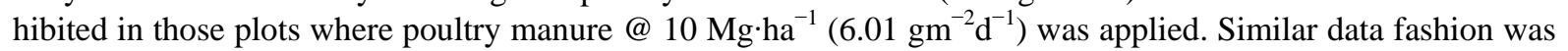
noted in 2011 as shown in Figures 5(a) and (d).

\subsection{Grain Yield}

Significantly maximum grain yield was recorded in the deep tillage practice ( 8.59 ton $\left.^{-1} a^{-1}\right)$, followed by the conventional tillage practice $\left(8.25\right.$ ton $\left.\cdot \mathrm{ha}^{-1}\right)$ that was at par with those of minimum tillage $\left(8.22 \mathrm{ton} \cdot \mathrm{ha}^{-1}\right)$ as shown in Figure 6(a). The minimum maize grain yield was recorded in the zero tillage practice (5.46 ton ha $^{-1}$ ) with no poultry manure in 2010 and almost similar data trend was observed during 2011 as shown in Figure 6(a). As far as poultry manure treatments were concerned, significantly more maize grain yield was recorded in $10 \mathrm{Mg} \cdot \mathrm{ha}^{-1}$ poultry manure treatment $\left(7.92 \mathrm{ton} \cdot \mathrm{ha}^{-1}\right)$ followed by the $5 \mathrm{Mg} \cdot \mathrm{ha}^{-1}$ poultry manure treatment $(7.48$ ton $\cdot \mathrm{ha}^{-1}$ ) and less grain yield was in the control treatment $\left(6.95\right.$ ton $\left.^{-1} \mathrm{~h}^{-1}\right)$ during 2010 . The same fashion of data was noted in the next year trial (2011) as shown in the Figure 6(b).

\subsection{Economic Analysis}

Economic viability accelerates the adaptability of agronomic techniques by the farming community on the basis

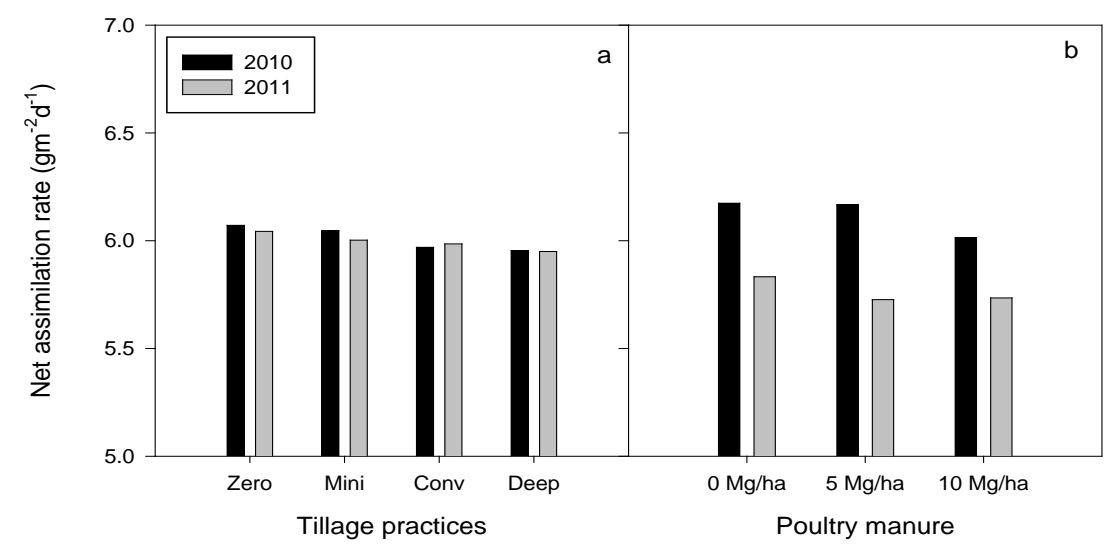

Figure 5. Net assimilation rate (NAR) as influenced by different tillage practices (a) and poultry manure levels (b) during 2010 and 2011, respectively.

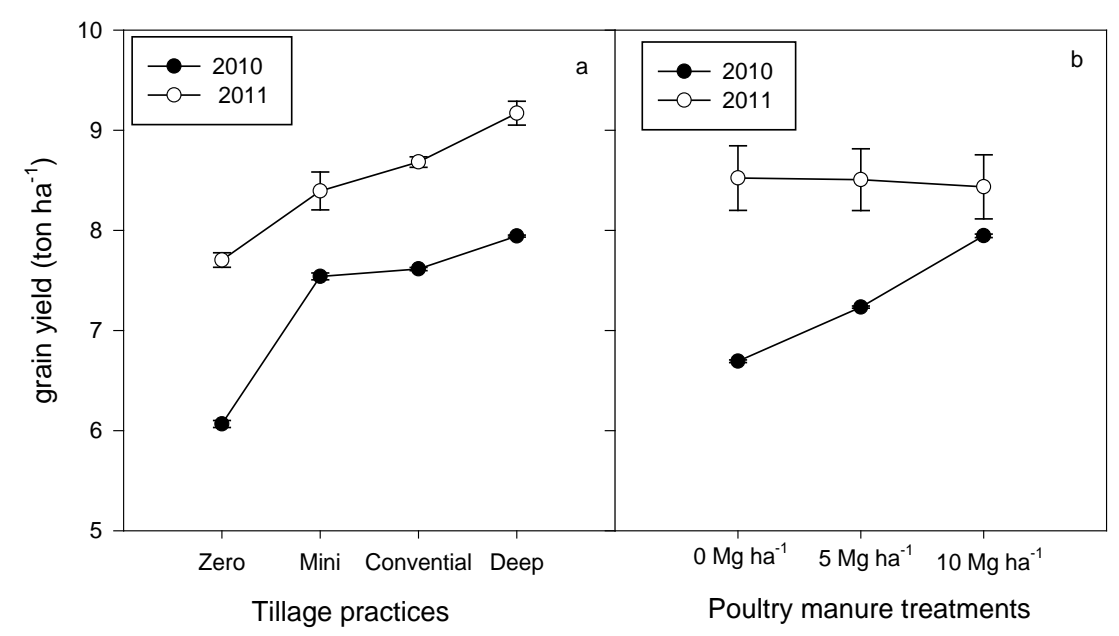

Figure 6. Grain yield as influenced by different tillage practices (a) and poultry manure levels (b) during 2010 and 2011, respectively. 
of net income return in the developing countries. The net return variability is more vital than variability in grain crop yield. The grain yield in the second growing season 2011 was higher than in the year 2010. In the second year cropping season, the effective rainfall at the critical stages of crop well favored the maize crop growth and development. Net income was calculated during both the years 2010 \& 2011 as shown in Table 2. During both the years of study, deep tillage gave the higher net income (Rs. 129,139 \& Rs. 153,945), followed by conventional tillage (Rs. 123,809 \& Rs. 154,735), minimum tillage (Rs. 125,324 \& Rs. 153,755) and zero tillage (Rs.

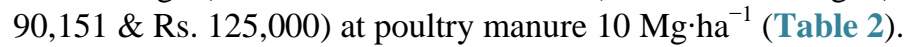

Highest BCR numerical value was calculated in minimum tillage ( $2.65 \& 2.91$ ), followed by conventional tillage ( $2.58 \& 2.87)$ and deep tillage ( $2.59 \& 2.79)$ while the lowest BCR was recorded in the zero tillage (2.11 \& 2.57) at the rate of $10 \mathrm{Mg} \cdot \mathrm{ha}^{-1}$ poultry manure (Table 2). Similarly, marginal analysis concluded that the zero

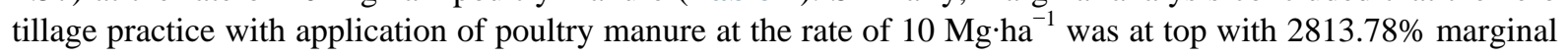
rate of return (MRR) in 2010 (Table 3) while during the year 2011, the higher MRR with 229.59\% was recorded

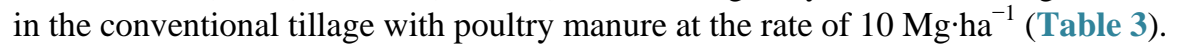

Sensitivity analyses indicates that the effect of increase or decrease in the inputs price on the treatments of the experiment that was applied. During 2010 \& 2011, the 10\% decrease in inputs prices has resulted in increase in net income (132,923 \& 161,822) and higher MRR (3137.63 \& 2567.11\%) as shown in Table 4, and vice versa in case of $10 \%$ increase in put price during the both year of study (Table 5). Crop productivity exhibited that grain yield efficiency versus the amount of money applied. Highest crop productivity was recorded in minimum tillage $\left(0.1081 \& 0.1139 \mathrm{Kg} \cdot \mathrm{Rs}^{-1}\right)$, followed by the conventional tillage $\left(0.1054 \& 0.1124 \mathrm{Kg} \cdot \mathrm{Rs}^{-1}\right)$ while the lowest crop productivity was calculated in zero tillage $\left(0.0900 \& 0.1009 \mathrm{Kg} \cdot \mathrm{Rs}^{-1}\right)$ with poultry manure at the rate of $10 \mathrm{Mg} \cdot \mathrm{ha}^{-1}$ during 2010 and 2011 respectively (Table 6).

Table 2. Net income and benefit-cost-ratio (BCR) during 2010 \& 2011 growing season.

\begin{tabular}{|c|c|c|c|c|c|c|c|c|}
\hline \multirow[t]{2}{*}{ Treatment } & \multicolumn{2}{|c|}{ Gross income } & \multicolumn{2}{|c|}{ Total cost of production } & \multicolumn{2}{|c|}{ Net income } & \multicolumn{2}{|c|}{$\mathrm{B}: \mathrm{C}$ ratio } \\
\hline & 2010 & 2011 & 2010 & 2011 & 2010 & 2011 & 2010 & 2011 \\
\hline \multicolumn{9}{|c|}{ Zero tillage } \\
\hline T1P1 & 133,688 & 177,395 & 96,512 & 105,091 & 37,176 & 72,304 & 1.39 & 1.69 \\
\hline T1P2 & 147,245 & 194,905 & 85,947 & 92,613 & 61,298 & 102,292 & 1.71 & 2.1 \\
\hline T1P3 & 164,885 & 204,425 & 74,734 & 79,425 & 90,151 & 125,000 & 2.21 & 2.57 \\
\hline \multicolumn{9}{|c|}{ Minimum tillage } \\
\hline T2P1 & 169,622 & 206,975 & 97,762 & 106,341 & 71,860 & 100,634 & 1.74 & 1.95 \\
\hline $\mathbf{T} 2 \mathbf{P} 2$ & 183,260 & 224,315 & 87,197 & 93,863 & 96,063 & 130,452 & 2.1 & 2.39 \\
\hline T2P3 & 201,308 & 234,430 & 75,984 & 80,675 & 125,324 & 153,755 & 2.65 & 2.91 \\
\hline \multicolumn{9}{|c|}{ Conventional tillage } \\
\hline T3P1 & 172,317 & 209,610 & 100,012 & 108,591 & 72,305 & 101,019 & 1.72 & 1.93 \\
\hline T3P2 & 185,220 & 226,695 & 89,447 & 96,113 & 95,773 & 130,582 & 2.07 & 2.36 \\
\hline T3P3 & 202,043 & 237,660 & 78,234 & 82,925 & 123,809 & 154,735 & 2.58 & 2.87 \\
\hline \multicolumn{9}{|c|}{ Deep tillage } \\
\hline T4P1 & 180,238 & 211735 & 103,012 & 111,591 & 77,226 & 100,144 & 1.75 & 1.9 \\
\hline T4P2 & 193,142 & 229,075 & 92,447 & 99,113 & 100,695 & 129,962 & 2.09 & 2.31 \\
\hline T4P3 & 210,373 & 239,870 & 81,234 & 85,925 & 129,139 & 153,945 & 2.59 & 2.79 \\
\hline
\end{tabular}

Price of input and output were subjected to local market of the cropping place in Pakistan. All prices are in Pakistani rupees (1 \$ = 106.05 PKR). Abbriviations: P1 = No poultry manure; P2 = $5 \mathrm{Mg} \cdot \mathrm{ha}^{-1}$ poultry manure; P3 = $10 \mathrm{Mg} \cdot \mathrm{ha}^{-1}$ poultry manure; T1 = Zero tillage; T2 = Minimum tillage; T3 = Conventional tillage; $\mathrm{T} 4$ = Deep tillage. 
Table 3. Marginal rate of return [MMR in \%] during 2010 and 2011.

\begin{tabular}{|c|c|c|c|c|c|c|c|c|c|c|}
\hline \multirow[t]{2}{*}{ Treatment } & \multicolumn{2}{|c|}{ Variable cost $\left(\mathrm{Rs}^{\prime} \mathrm{ha}^{-1}\right)$} & \multicolumn{2}{|c|}{ Marginal cost $\left(\mathbf{R s} \cdot h^{-1}\right)^{-1}$} & \multicolumn{2}{|c|}{ Net Income $\left(\mathbf{R s} \cdot \mathrm{Ha}^{-1}\right)$} & \multicolumn{2}{|c|}{$\begin{array}{c}\text { Marginal Net } \\
\text { benefit (Rs } \cdot \mathbf{h a}^{-1} \text { ) }\end{array}$} & \multicolumn{2}{|c|}{$\begin{array}{l}\text { Marginal rate } \\
\text { of return (\%) }\end{array}$} \\
\hline & 2010 & 2011 & 2010 & 2011 & 2010 & 2011 & 2010 & 2011 & 2010 & 2011 \\
\hline T1P3 & 74,734 & 79,425 & & & 90,151 & 125,000 & & & & \\
\hline T2P3 & 75,984 & 80,675 & 1250 & 1250 & 125,324 & 153,755 & 35,173 & 28,755 & 2813.87 & 4.347 \\
\hline T4P3 & 81,234 & - & 5250 & - & 129,139 & - & 3815 & - & 72.76 & - \\
\hline T43P3 & - & 82,925 & - & 2250 & - & 154,735 & - & 980 & - & 229.59 \\
\hline
\end{tabular}

Abbriviations: $\mathrm{P} 1$ = No poultry manure; $\mathrm{P} 2$ = $5 \mathrm{Mg} \cdot \mathrm{ha}^{-1}$ poultry manure; $\mathrm{P} 3=10 \mathrm{Mg} \cdot \mathrm{ha}^{-1}$ poultry manure; $\mathrm{T} 1=\mathrm{Zero}$ tillage; $\mathrm{T} 2$ = Minimum tillage; $\mathrm{T} 3$ = Conventional tillage; $\mathrm{T} 4$ = Deep tillage.

Table 4. Sensitivity analysis as input prices decreased 10\% during 2010 and 2011.

\begin{tabular}{|c|c|c|c|c|c|c|c|c|c|c|}
\hline \multirow[t]{2}{*}{ Treatment } & \multicolumn{2}{|c|}{ Variable cost $\left(\mathbf{R s} \cdot \mathrm{ha}^{-1}\right)$} & \multicolumn{2}{|c|}{ Marginal cost $\left(\mathrm{Rs}^{\prime} \cdot \mathrm{ha}^{-1}\right)$} & \multicolumn{2}{|c|}{ Net Income (Rs·Ha $\left.{ }^{-1}\right)$} & \multicolumn{2}{|c|}{$\begin{array}{l}\text { Marginal Net } \\
\left.\text { benefit (Rs·ha' }{ }^{-1}\right)\end{array}$} & \multicolumn{2}{|c|}{$\begin{array}{l}\text { Marginal rate } \\
\text { of return (\%) }\end{array}$} \\
\hline & 2010 & 2011 & 2010 & 2011 & 2010 & 2011 & 2010 & 2011 & 2010 & 2011 \\
\hline T1P3 & 67,261 & 71,482 & & & 97,624 & 132,942 & & & & \\
\hline T2P3 & 68,386 & 72,607 & 1125 & 1125 & 132,923 & 161,822 & 35,298 & 28,880 & 3137.63 & 2567.11 \\
\hline T4P3 & 73,111 & 74,632 & 4725 & 2025 & 137,263 & 163,027 & 4340 & 1205 & 91.85 & 59.51 \\
\hline
\end{tabular}

Abbriviations: $\mathrm{P} 1$ = No poultry manure; $\mathrm{P} 2$ = $5 \mathrm{Mg} \cdot \mathrm{ha}^{-1}$ poultry manure; $\mathrm{P} 3=10 \mathrm{Mg} \cdot \mathrm{ha}^{-1}$ poultry manure; $\mathrm{T} 1=\mathrm{Zero}$ tillage; $\mathrm{T} 2$ = Minimum tillage; $\mathrm{T} 3$ = Conventional tillage; $\mathrm{T} 4$ = Deep tillage.

Table 5. Sensitivity analysis as input prices increased 10\% during 2010 and 2011.

\begin{tabular}{|c|c|c|c|c|c|c|c|c|c|c|}
\hline \multirow[t]{2}{*}{ Treatment } & \multicolumn{2}{|c|}{ Variable cost $\left(\mathrm{Rs}^{\cdot} \cdot \mathrm{ha}^{-1}\right)$} & \multicolumn{2}{|c|}{ Marginal cost $\left(\mathbf{R s} \cdot h a^{-1}\right)$} & \multicolumn{2}{|c|}{ Net Income $\left(\mathrm{Rs} \cdot \mathrm{Ha}^{-1}\right)$} & \multicolumn{2}{|c|}{ 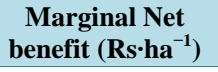 } & \multicolumn{2}{|c|}{$\begin{array}{l}\text { Marginal rate } \\
\text { of return (\%) }\end{array}$} \\
\hline & 2010 & 2011 & 2010 & 2011 & 2010 & 2011 & 2010 & 2011 & 2010 & 2011 \\
\hline T1P3 & 82,207 & 87,367 & & & 82,678 & 117,057 & & & & \\
\hline T2P3 & 83,582 & 88,742 & 1375 & 1375 & 117,726 & 145,687 & 35,048 & 28,639 & 2548.97 & 2082.18 \\
\hline T4P3 & 89,357 & 91,217 & 5775 & 2475 & 121,016 & 146,442 & 3290 & 755 & 56.97 & 30.5 \\
\hline
\end{tabular}

Abbriviations: $\mathrm{P} 1$ = No poultry manure; $\mathrm{P} 2$ = $5 \mathrm{Mg} \cdot \mathrm{ha}^{-1}$ poultry manure; $\mathrm{P} 3$ = $10 \mathrm{Mg} \cdot \mathrm{ha}^{-1}$ poultry manure; $\mathrm{T} 1=\mathrm{Zero}$ tillage; $\mathrm{T} 2$ = Minimum tillage; $\mathrm{T} 3$ = Conventional tillage; T4 = Deep tillage.

\section{Discussion}

The fewer days to start emergence in deep tillage sown crop might be due to more fine soil tilth, less soil clods and sufficient moisture availability which may promoted the seeds germination. The more soil temperature might have accelerated the seeds germination and emergence. In the zero tillage sown crop, the subsurface soil temperature was cooler which might be slower down the seeds germination. Furthermore, the compaction of the soil may delay the seeds emergence in the zero tillage. The results are in accordance with those of Yusuf [15] who documented that more germination percentage of sunflower seeds grown in rice field was recorded in disc plough treatment followed by rotavator and the lowest germination count was observed in zero tillage treatment. More time to start seedling emergence at $10 \mathrm{Mg} \cdot \mathrm{ha}^{-1}$ poultry manure treatment may be due a positive correlation between the poultry manure and N-mineralization. Similar results was observed by Eneje and Nwosu [16] who reported a positive correlation between organic carbon and N-mineralization that resulted in more maize seed germination time in cow dung treated plots than the control plot.

This differentiation among the leaf area index of maize in different tillage practices might be due to extraction of more nutrients, minerals and water as the plant roots were gone deeper soil profile for extra inputs. Promoted effect of different tillage practices on leaf area index was documented by those of Yusuf [15] who stated that the shallow rooted plants had significantly lower leaf area index as compared to chiseled sown crop which might be due to less area of soil under surveillance of shallow root crop and hence less nutrients and water was available.

More days of leaf area duration in the deep tillage crop might be due to more availability of nutrients and wa- 
Table 6. Crop productivity during 2010 and 2011 growing season.

\begin{tabular}{|c|c|c|c|c|c|c|}
\hline \multirow[t]{2}{*}{ Treatment } & \multicolumn{2}{|c|}{ Product output } & \multicolumn{2}{|c|}{ Total cost of production $\left(\mathrm{Rs}^{\prime} \cdot \mathrm{ha}^{-1}\right)$} & \multicolumn{2}{|c|}{ Crop productivity } \\
\hline & 2010 & 2011 & 2010 & 2011 & 2010 & 2011 \\
\hline & \multicolumn{6}{|c|}{ Zero tillage } \\
\hline T1P1 & 5457 & 6956.67 & 96,512 & 105,091 & 0.0565 & 0.0662 \\
\hline T1P2 & 6010 & 7643.33 & 85,947 & 92,613 & 0.0699 & 0.0825 \\
\hline \multirow[t]{2}{*}{ T1P3 } & 6730 & 8016.67 & 74,734 & 79,425 & 0.09 & 0.1009 \\
\hline & \multicolumn{6}{|c|}{ Minimum tillage } \\
\hline T2P1 & 6923 & 8116.67 & 97,762 & 106,341 & 0.0708 & 0.0763 \\
\hline T2P2 & 7480 & 8796.67 & 87,197 & 93,863 & 0.0859 & 0.0937 \\
\hline \multirow[t]{2}{*}{ T2P3 } & 8217 & 9193.33 & 75,984 & 80,675 & 0.1081 & 0.1139 \\
\hline & \multicolumn{6}{|c|}{ Conventional tillage } \\
\hline T3P1 & 7033 & 9220 & 100,012 & 108,591 & 0.0703 & 0.0757 \\
\hline T3P2 & 7560 & 8890 & 89,447 & 96,113 & 0.0845 & 0.0925 \\
\hline \multirow[t]{2}{*}{ T3P3 } & 8247 & 9320 & 78,234 & 83,925 & 0.1054 & 0.1124 \\
\hline & \multicolumn{6}{|c|}{ Deep tillage } \\
\hline T4P1 & 7357 & 8303.33 & 103,012 & 111,591 & 0.0714 & 0.0744 \\
\hline T4P2 & 7883 & 8983.33 & 92,447 & 99,113 & 0.0853 & 0.0906 \\
\hline T4P3 & 8587 & 9406.67 & 81,234 & 85,925 & 0.1057 & 0.1095 \\
\hline
\end{tabular}

Price of input and output were subjected to local market of the cropping place in Pakistan. All prices are in Pakistani rupees (1 \$ = $106.05 \mathrm{PKR}$ ). Abbriviations: $\mathrm{P} 1$ = No poultry manure; $\mathrm{P} 2=5 \mathrm{Mg} \cdot \mathrm{ha}^{-1}$ poultry manure; P3 = $10 \mathrm{Mg} \cdot \mathrm{ha}^{-1}$ poultry manure; T1 = Zero tillage; T2 = Minimum tillage; T3 $=$ Conventional tillage; $\mathrm{T} 4=$ Deep tillage.

ter to the crop plant as plant root may go to deeper soil profile. The higher leaf area duration might be due to more leaf area index in deep tillage treatment [15]. Moreover, differences in CGR of the treatments could be ascribing to variations in the amount of light intercepted as well as its efficiency of usage by the LAI and ultimately more LAD.

The higher amount of poultry manure increased the nutrients holding capacity and availability over lower poultry manure dose and control which caused the leaves to remain green for longer period [17]. The maize plants sown in the control plot showed lower leaf area index might be due to higher leaching and volatilization of nitrogen as compared to organic matter added plots. Khaliq et al. [18] and Valadabadi and Farahani [19] reported that the greater leaf area expansion was noted in the long period availability of nitrogen over the shorter period nitrogen availability. Similarly Cha-um et al. [20] found significant correlation between LAI and photosynthesis rate. Efthimiadou et al. [21] reported this increase in photosynthesis rate is due to more availability of nitrogen and also correlation analysis of photosynthesis rate with transpiration was positive and significant. Higher LAD at the higher poultry manure dose (@10 Mg.ha ${ }^{-1}$ ) might be due to more and balance nutrients availability to the plant throughout the plant life cycle which might have kept the plant leaves green and hence greater LAD. Moreover, the poultry manure may increase the water holding capacity of the soil that may provide sustainable water to the plant root. These results are supported by those of Ali et al. [22] that higher LAD was exhibited in poultry manure treatments as compared to press mud of sugarcane and control treatments. Overall LAD was higher in the 2011 as compared to 2010, it might be due to more rainfall in 2011 and lower temperature provided the more time for leaves to be remaining green. Hence higher was the LAI, higher LAD was achieved in 2011. Higher CGR in the poultry manure treatments might be due to better utilization of available nutrients in the soil during the crop growth period as compared to control. Furthermore, higher LAI might have resulted in more crop growth rate [23]. Poultry manure significantly increased the crop growth rate of maize crop over other fertilizer sources [22]. 
Seasonal effect was observed during the both years of crop growth; higher CGR was in recorded 2011 and lower was in the 2010. Thus differences in CGR among different tillage practices and poultry manure treatments during the crop growth period might have resulted in the variation of environmental conditions such as radiation which directly influenced the plant biomass production [24].

Promising crop growth rate indifferent poultry manure treatments might be due to effective utilization of available micro and macro nutrients in the soil profiles during the whole crop growth period compared to control (where no poultry manure was applied) resulting in higher leaf area index [23]. The increased in CGR of maize crop over the chemical fertilizers that may help the maize plant in more photosynthates production and accumulation and finally bold grains were achieved [22]. Similarly, Ayoola and Makinde [25] reported that higher grain yield in poultry manure treatments and lower in synthetic fertilizers plot and in control (no poultry manure was applied).

Higher net income was calculated in the deep tillage with $10 \mathrm{Mg} \cdot \mathrm{ha}^{-1}$ poultry manure was might be due to more grain yield while less BCR was due to higher cost of production as compared to minimum tillage that have maximum BCR as compared to all other experimental treatments during 2010 and 2011. Sarwar et al. [26] performed field experiment and concluded that through use of organic manures at the rate of $12 \mathrm{Mg} \mathrm{ha}^{-1}$ along with various chemical fertilizer rates gave the more net income than inorganic fertilizers or control. As regards to MRR, the higher MRR was achieved in those treatments where less cost of inputs was applied and the same was with sensitivity analyses. Higher crop productivity in the minimum tillage with at the rate of $10 \mathrm{Mg} \cdot \mathrm{ha}^{-1}$ poultry manure was due to less cost of production in the form of less tillage operations and cheap poultry manure as compared to deep tillage where deep tillage operations were increase the cost of production that resulted in lower crop productivity. Although, the deep tillage practice was produced the higher grain yield and net income.

\section{Conclusion}

The study of 2010 and 2011 cropping seasons evaluated the maize response to tillage practices and poultry manure in a clay loam soil of sub-tropical condition. In assessing the emergence and crop growth characteristics during the research period, deep ploughing was found to have provided the more favorable soil environment for maize production than no-tillage and minimum tillage in the study area. Poultry manure application at the rate of $10 \mathrm{Mg} \cdot \mathrm{ha}^{-1}$ was found superior than control and $5 \mathrm{Mg} \cdot \mathrm{ha}^{-1}$ poultry manure level. On the basis of economic ana-

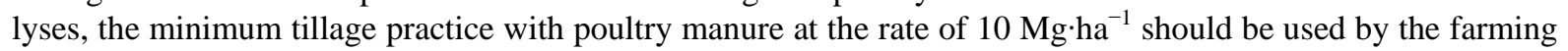
community as they have produced the higher BCR, MRR and crop productivity over the conventional, deep and zero tillage treatments.

\section{Acknowledgements}

Authors are thankful to Higher Education Commission (HEC) of Pakistan for the financial assistance during the whole study period.

\section{References}

[1] Government of Pakistan (GoP) (2010) Economic Survey of Pakistan. Ministry of Food, Agriculture and Livestock (Federal Bureau of Statistics), Islamabad, 33-35.

[2] Rosner, J., Zwatz, E., Klik, A. and Gyuricza, C. (2008) Conservation Tillage Systems-Soil-Nutrient and Herbicide Loss in Lower Austria and the Mycotoxin Problem. 15th International Congress of ISCO, Geographical Research Institute, Hungary.

[3] Motavalli, P.P., Stevens, W.E. and Hartwig, G. (2003) Remediation of Subsoil Compaction and Compaction Effects on Corn N Availability by Deep Tillage and Application of Poultry Manure in a Sandy-Textured Soil. Soil \& Tillage Research, 71, 121-131. http://dx.doi.org/10.1016/S0167-1987(03)00041-2

[4] Gul, B., Marwat, K.B., Hassan, G., Khan, A., Hashim, S. and Khan, I.A. (2009) Impact of Tillage, Plant Population and Mulches on Biological Yield of Maize. Pakistan Journal of Botany, 41, 2243-2249.

[5] Borghei, A.M., Taghinejad, J., Minaei, S., Karimi, M. and Varnamkhasti, M.G. (2008) Effect of Subsoiling on Soil Bulk Density, Penetration Resistance and Cotton Yield in Northwest of Iran. International Journal of Agriculture and Biology, 10, 120-123.

[6] Mullins, G.L., Alley, S.E. and Reeves, D.W. (1998) Tropical Maize Response to Nitrogen and Starter Fertilizer under Strip and Conventional Tillage Systems in Southern Alabama. Soil \& Tillage Research, 45, 1-15. 
http://dx.doi.org/10.1016/S0167-1987(97)00069-X

[7] Barbosa, L.R., Diaz, O. and Barber, R.G. (1989) Effects of Deep Tillage on Soil Properties, Growth and Yield of Soya in a Compacted Ustochrept in Santa Cruz, Bolivia. Soil \& Tillage Research, 15, 51-63. http://dx.doi.org/10.1016/0167-1987(89)90063-9

[8] Bocchi, S. and Tano, F. (1994) Effect of Cattle Manure and Components of Pig Slurry on Maize Growth and Production. European Journal of Agronomy, 3, 235-241.

[9] Boateng, S., Zickermann, A.J. and Kornaharens, M. (2006) Effect of Poultry Manure on Growth and Yield of Maize. West African Journal of Applied Ecology, 9, 1-11.

[10] Ipimoroti, R.R., Daniel, M.A. and Obatolu, C.R. (2002) Effect of Organo-Mineral Fertilizer on Tea Growth at Kusuku, Mambilla Plateau, Nigeria. Moor Journal of Agricultural Research, 3, 180-183.

[11] Makinde, E.A., Akande, M.O. and Agboola, A.A. (2001) Effects of Fertilizer Type on Performance of Melon in a Maize-melon Intercrop. ASSET Series, A (2), 151-158.

[12] Amujiyegbe, B.J., Opabode, J.T. and Olayinka, A. (2007) Effect of Organic and Inorganic Fertilizer on Yield and Chlorophyll Content of Maize (Zea mays L.) and Sorghum (Sorghum bicolor L.) Moench. African Journal of Biotechnology, 6, 1869-1873.

[13] Mohamed, S.A., Ewees, S.A., Sawsan, A., Seaf, E.Y. and Dalia, M.S. (2008) Improving Maize Grain Yield and Its Quality Grown on a Newly Reclaimed Sandy Soil by Applying Micronutrients, Organic Manure and Biological Inoculation. Research Journal of Agriculture and Biological Sciences, 4, 537-544.

[14] CIMMYT (1988) From Agronomic Data to Farmer Recommendations. An Economic Training Biometrical Approach. McGraw Hill Book Co., New York, 400-428.

[15] Yusuf, D.D. (2006) Effect of Variation in Tillage Systems on Maize (Zea mays L.) Establishment and Grain Yield in a Semi-Arid Tropical Climate. Journal of Agricultural Science and Technology, 8, 171-179.

[16] Eneje, R.C. and Nwosu, C.J. (2012) Cow Dung and Cassava Peel Effect on Selected Soil Nutrient Indices and Germination of Maize. Science Journal of Agricultural Research \& Management, 152, 1-6.

[17] Gungula, D.T., Kling, J.G. and Togun, A.O. (2003) CERES Maize Predictions of Maize Phenology under Nitrogen Stressed Conditions in Nigeria. Agronomy Journal, 95, 892-899. http://dx.doi.org/10.2134/agronj2003.0892

[18] Khaliq, A., Ahmad, A., Hussain, A. and Ali, M.A. (2009) Maize Hybrids Response to Nitrogen Rates at Multiple Locations in Semiarid Environment. Pakistan Journal of Botany, 41, 207-224.

[19] Valadabadi, S.A. and Farhani, H.A. (2010) Effect of Planting Density and Pattern on Physiological Growth Indices and Maize (Zea mays L.) under Nitrogenious Fertilizer Application. Journal of Agricultural Extension and Rural Development, 2, 40-47.

[20] Cha-um, S., Nhung, N.T.H. and Kirdmanee, C. (2010) Effect of Mannitoland Salt-Induced Iso-Osmotic Stress on Proline Accumulation, Hotosynthetic Abilities and Growth Characters of Rice Cultivars (Oryzasativa L). Pakistan Journal of Botany, 42, 927-941.

[21] Efthimiadou, A., Bilalis, D., Karkanis, A. and Williams, B.F. (2010) Combined Organic/Inorganic Fertilization Enhance Soil Quality and Increased Yield, Photosynthesis and Sustainability of Sweet Maize Crop. Australian Journal of Crop Science, 4, 722-729.

[22] Ali, A., Tahir, M. and Yaseen, M. (2012) Growth and Yield Response of Hybrid Maize through Integrated Phosphorus Management. Pakistan Journal of Life and Social Science, 10, 59-66.

[23] Carpenter, A.C. and Board, J.E. (1997) Branch Yield Components Controlling Soybean Yield Stability across Plant Populations. Crop Science, 37, 885-891. http://dx.doi.org/10.2135/cropsci1997.0011183X003700030031x

[24] Horie, T. and Sakuratani, T. (1985) Studies on Crop-Weather Relationship Model of Rice. I. Relation between Absorbed Solar Radiation by the Crop and Dry Matter Production. Agricultural and Forest Meteorology, 40, 31-242.

[25] Ayoola, O.T. and Makinde. E.A. (2009) Maize Growth, Yield and Soil Nutrient Changes with N-Enriched Organic Fertilizers. African Journal of Food, Agriculture, Nutrition and Development, 9, 580-592.

[26] Sarwar, G., Hussain, N., Schmeisky, H., Suhammad, S., Ibrahim, M. and Ahmad, S. (2008) Efficiency of Various Organic Residues for Enhancing Rice-Wheat Production under Normal Soil Conditions. Pakistan Journal of Botany, 40, 2107-2113. 